as this arrangement simplifies the construction and renders it unnecessary to excavate a basement. The propeller or axial-flow type of fan has also proved itself to be rather more adaptable generally to the requirements of timber kilns than has the blower or centrifugal type; the leaflet, therefore, is confined to the overhead-propeller fan types of kiln.

\section{Micronesia and Melanesia}

"Island Peoples of the Western Pacific, Micronesia and Melanesia" is the title of another volume in the series of War Background Studies published by the Smithsonian Institution. It is compiled by Herbert W. Krieger, ethnological curator, U.S. National Museum. The work is exactly what is required by anyone following the War in the Pacific at the present time. The Caroline Islands, the Gilbert Islands, the Marshall Islands, Bougainville and the Solomons, New Britain and New Ireland are all mentioned. To begin with, there is a general account of the region and its discovery and early history. This is followed by particular accounts of Micronesia and its islands, and similarly of Melanesia. The description of the native peoples and their customs will prove particularly interesting to many readers. There are throughout a large number of excellent illustrations.

\section{Public Health in Colombia}

THF April issue of the Boletin de la Oficina Sanitaria Panamericana contains an interesting paper on this subject by Dr. Eduardo Santos, a former president of the Republic of Colombia. He states that in spite of adverse conditions 140 aqueducts, thirty sewers and twenty new hospitals have been constructed in the Republic in the past fifteen or twenty years. More than eight hundred institutions are now devoted to mateinity and child welfare, and the prenatal services number at present 126 as compared with 62 in 1937 . During this period hospital beds have been increased from 11,422 to 16,322 , and fortyfive hospitals with a total of 1,500 beds are now under construction. There are at present twenty-five tuberculosis dispensaries as compared with only four in 1937. The yellow-fever campaign is being carried on by the Government in collaboration with the Rockefeller Institute, which has an excellent labora. tory at Bogotá devoted to the production of yellow fever vaccine. The campaign against typhus and bartonellosis is continuing. There is practical cooperation between the State and private agencies, such as the Red Cross, the Colombia Anti-Tuberculosis League, the Association for the Care of Lepers and other groups.

\section{The Health of France}

THE underground newspaper Arenir Medical, as quoted by The Lancet of February I2, gives the following account of the effects of food shortage in France. Adolescents are losing weight. Want of strength reduces the competence of adults for their work and favours accidents. Hypotension and anæmia are common. Bone decalcification and rickets are seen as in the regions invaded in 1914-18. 'War amenorrhœa' is prevalent in girls and young women. Famine œedema is becoming increasingly prevalent in private and hospital practice. Tuberculosis has risen by at least 20-30 per cent and assumes malignant forms which are rapidly fatal, especially in young people. Pregnant women being inadequately nourished bear underweight infants with a growing proportion of still. births.

\section{Red Blood Cells as Wound Dressings}

Av annotation in the Lancet (252, Feb. 19, 1944) directs attention to experiments by J. J. Moorhead and L. J. Unger (Amer. J. Surgery, 59, 104; 1943) on the application of pooled human erythrocytes, collected and stored aseptically, to wounds. The red cells form a gelatinous mass which dries over the wound, and it is claimed that sepsis subsides under this, while healthy granulations develop. T. H. Seldon and H. H. Young (Proc. Mayo Clin., 18, 385 ; 1943) have experimented with a dried and powdered concentrate of red cells applied once or twice daily. In some cases this application smelt noticeably; in others it produced severe burning pain and was discontinued. In three cases it gave good results. These authors think that the method deserves further investigation and suggest that bovine erythrocytes might be tried.

\section{An Astronomical Paradox}

Science SERvice has directed attention to an investigation by Dr. Otto Struve, director of Yerkes Observatory, of 48 Libræ, which "presents a notable paradox". This star reveals the characteristics of a super-giant and also of a main-sequence star. At wave-lengths longer than 3,650 A., a main-sequence $B$-type star is suggested; but at shorter wavelengths the spectrum resembles a super-giant $A$-type star. During, the last ten to twenty years strong metallic absorption lines have developed. Some spectral lines arising in the gaseous shell surrounding the star are sharp and strong, while others are diffuse and weaker. On the whole, the observations indicate stratification in the tenuous shell surrounding the star. The outside layers are rotating slowly while the inner layers have a much higher speed of rotation, and at times they seem to be contracting and expanding. It is pointed out that there is a certain amount of resemblance between the shell surrounding this star and that observed in 1940 surrounding Pleione, but the peculiarities in $48 \mathrm{Libræ}$ are more difficult to explain than they were in Pleione.

\section{Announcements}

Prof. W. H. Pearsall, F.R.S., professor of botany in the University of Sheffield, has been appointed Quain professor of botany in University College, London.

Mr. Walter Fitzgerald, senior lecturer in geography in the University of Manchester, has been appointed professor of geography in the University in succession to Prof. H. J. Fleure, who retires next September.

Dr. Otro Stritve, director of the Yerkes and the McDonald Observatories, has been awarded the Gold Medal of the Royal Astronomical Society for his work on the observation and interpretation of the spectra of stars and nebulæ.

Prof. C. H. Best, professor of physiology in the University of Toronto, and $\mathrm{Mr}$. $\mathrm{T}$. Whittemore, archrologist, have been elected members of the Athenæum under the rule for special elections.

At the annual general meeting of the Society of Public Analysts and Other Analytical Chemists, held on March 1 , the following officers were elected : President : Mr. S. Ernest Melling; Hon. Treasurer : Mr. George Taylor; Hon. Secretary: Mr. Lewis Eynon. 